$\begin{array}{r}\text { Phinisi Integration Review } \\ \text { Vol. 1, No.2, Agustus 2018 Hal 141-148 } \\ \text { Website: http://ojs.unm.ac.id/pir } \\ \text { p-ISSN: 2614-2325 dan e-ISSN: 2614-2317 } \\ \hline\end{array}$

\title{
Pengembangan Media Audio Visual Berbasis Budaya Lokal Sipakatau Dalam Pembelajaran IPS Pada Peserta Didik SD Se Gugus SDN 57 Campaga Kabupaten Bantaeng
}

\author{
Sri Wahyuni \\ Pendidikan IPS Kekhususan Pendidikan IPS ke SD-an \\ Program Pascasarjana Universitas Negeri Makassar \\ email: sriewahyunibbm@gmail.com
}

\begin{abstract}
Abstrak. Penelitian ini bertujuan untuk (1) mengetahui gambaran kebutuhan pengembangan media audio visual berbasis budaya lokal sipakatau dalam pembelajaran IPS, (2) mengetahui gambaran desain pengembangan media audio visual berbasis budaya lokal dalam pembelajaran IPS, dan (3) mengetahui tingkat kevalidan, kepraktisan, dan keefektifan media audio visual berbasis budaya lokal sipakatau dalam Pembelajaran IPS. Metode penelitian yang digunakan Penelitian dan Pengembangan (Research and Development). Langkah penelitian adalah perumusan tujuan pembelajaran dengan terlebih dahulu melakukan pemetaan KI, KD, dan IPK, selanjutnya pengembangan materi pembelajaran, penulisan naskah, penulisan narasi, rekaman suara, pengujian internal desain, dan pembuatan produk. Hasil analisis kebutuhan pengembangan media audio visual berbasis budaya lokal sipakatau sangat dibutuhkan, sebab dapat memotivasi siswa berpartisipasi aktif agar pembelajaran IPS menjadi menyenangkan demi tercapainya tujuan pembelajaran. Juga sekaligus sebagai sarana pembinaan karakter siswa agar bisa hidup saling menghormati dan menghargai sesama manusia. Hasil validasi menunjukkan bahwa produk media pembelajaran beserta instrumennya dinyatakan dalam kategori sangat valid. Respon guru sebagai pengguna media menyatakan bahwa media pembelajaran berada pada kategori sangat praktis. Keefektifan penggunaan media pembelajaran dibuktikan dengan observasi aktivitas siswa dalam pembelajaran IPS dan tes hasil belajar siswa. Hasil observasi ditemukan bahwa rata-rata aktivitas siswa berada pada kategori sangat baik. Tes hasil belajar menunjukkan bahwa skor rata-rata setelah pembelajaran lebih besar daripada skor rata-rata sebelum pembelajaran.
\end{abstract}

Kata kunci: Media audio visual, budaya lokal, pembelajaran IPS

\begin{abstract}
This study aims to (1) find out the description of the needs of the development of audio-visual media based on sipakatau local culture in social science learning, (2) to know the description of the design of the development of audio-visual media based on sipakatau local culture in social science learning, and (3) to know the level of validity, effectiveness of audio-visual media based on sipakatau local culture in social science learning. The research method used is Research and Development. The steps of this research is the formulation of learning objectives by first doing the mapping of Core Competencies, Basic Competencies, and Indicators of Competence Achievement, furthermore development of learning materials, script writing, narrative writing, sound recording, internal design testing, and product manufacture. The result of needs analysis of audio visual media development based on sipakatau local culture sipakatau is needed, because it can motivate students to actively participate in social science learning become fun for the achievement of learning objectives. Also at the same time as a means of fostering the character of students in order to live in mutual respect and respect for
\end{abstract}


humanity. Validation results indicate that the learning media products and their instruments are expressed in very valid categories. The teacher's response as a media user states that the learning media is in a very practical category. The effectiveness of the use of instructional media is evidenced by student activity observation in social science learning and student learning result test. The result of observation found that the average of student activity is in very good category. The test of learning results shows that the mean score after learning is greater than the average score before the learning.

Keyword: Audio visual media, local culture, social science learning

Ini adalah artikel dengan akses terbuka dibawah licenci CC BY-NC-4.0

(https://creativecommons.org/licenses/by-nc/4.0/ )

\section{PENDAHULUAN}

Pendidikan selalu dijadikan standar atau tolok ukur moralitas dan mentalitas generasi bangsa. Sehingga untuk meningkatkan hal tersebut, lembaga pendidikan terus melakukan pembenahan, baik dari segi kebijakan maupun dalam hal pembenahan kurikulum demi perbaikan mutu pendidikan yang didasarkan pada kebutuhan peserta didik, agar nantinya lahir generasi penerus bangsa yang bermoral dan bermartabat.

Sesuai dengan Permendikbud Nomor 22 Tahun 2016 tentang Standar Proses Pendidikan Dasar dan Menengah lebih menekankan pada penciptaan manusia yang mandiri, mampu memecahkan masalah, mempunyai kepribadian yang kuat, inovatif dan kreatif, menguasai teknologi, pembelajarannya terpadu, membutuhkan kreativitas guru, dan minset yang bagus untuk mendukung keterampilan dalam mengaplikasikannya ke dalam pembelajaran. Oleh karena itu, guru diberikan peluang untuk mengembangkan potensi lokal dan nilai-nilai budaya yang terkandung di dalamnya baik sosial, ekonomi, politik, dan sebagainya.

Somantri (2001: 134) mengusulkan untuk melakukan pengembangan dan pembaharuan pada pembelajaran IPS agar berpotensi dalam meningkatkan mutu pendidikan. Sebagaimana yang dijelaskan oleh Kosasih (1994) dalam Trianto (2010: 173) bahwa dalam pembelajaran IPS membahas tentang hubungan manusia dan lingkungan masyarakat dimana peserta didik tumbuh dan berkembang sebagai bagian dari masyarakat. Hal ini bertujuan untuk mempersiapkan peserta didik agar mampu memecahkan masalah yang ditemui dalam masyarakat sehingga menjadikannya mengerti dan memahami lingkungan sosial masyarakatnya.
Ariyani dan Haryanto (2010: 122) juga menjelaskan bahwa pada umumnya terdapat banyak media pembelajaran yang dapat digunakan dalam kegiatan pembelajaran. Oleh karena itu, guru yang cermat dan tanggap terhadap kebutuhan belajar peserta didik harus menggunakan metode dan media yang tepat dalam pembelajaran, sehingga peserta didik dapat termotivasi untuk belajar.

Potensi budaya lokal yang masih dipegang teguh oleh masyarakat perlu dijadikan dasar dalam pengembangan peragkat pembelajaran, agar penyajian pembelajaran dapat dikonkritkan sesuai lingkungan masyarakat setempat. Hal ini juga berpengaruh pada upaya mempertahankan kearifan budaya local masyarakat setempat dalam diri peserta didik agar peserta didik tidak tercerabut dari identitas lokalnya, juga untuk menjinakkan pengaruh globalisasi yang semakin dekat dengan masyarakat pedesaan.

Ditemukan beberapa masalah dalam pembelajaran IPS yang menunjukkan tidak terwujudnya konsespsi ideal pembelajaran. Diantaranya adalah penyajian pembelajaran IPS yang masih bersifat tekstual atau dalam artian penyajian pembelajaran terfokus pada buku pelajaran yang masih bersifat umum. Dibuktikan dengan adanya guru yang mengeluhkan tentang buku pedoman yang digunakan, isisnya masih dominan membahas tentang budaya di luar Sulawesi Selatan. Olehnya itu, hal ini mengindikasikan bahwa pembelajaran disajikan tidak berdasar pada potensi daerah dan sosial budaya masyarakat setempat. Selain itu media pembelajaran yang digunakan masih bersifat konvensional dan monoton yang menimbulkan sikap pasif terhadap peserta didik. Bahkan ada yang mengeluhkan kekurangan alat peraga dalam pembelajaran IPS. Ada juga yang masih menggunakan media gambar yang sudah jadi, 
yang kadang kala tidak sesuai dengan indikator dan tujuan pembelajaran. Hal tersebut diperparah oleh perencanaan pembelajaran IPS termasuk pemetaan silabus dan RPP tidak disesuaikan dengan kebutuhan peserta didik.

Berbagai masalah yang ditemukan dari hasil observasi dan wawancara pra penelitian, maka calon peneliti merasa tertarik melakukan penelitian dan pengembangan dalam pembelajaran IPS yang dalam penyajiannya mendasarkan pada potensi daerah, sosial budaya masyarakat setempat, dan kebutuhan peserta didik. Sehingga calon peneliti memfokuskan pada penelitian pengembangan media audio visual berbasis budaya lokal sipakatau dalam pembelajaran IPS kelas IV SD Se Gugus SDN 57 Campaga Kabupaten Bantaeng.

Permasalahan dalam penelitian ini adalah bagaimana gambaran kebutuhan pengembangan media audio visual berbasis budaya lokal sipakatau, bagaimana gambaran desain pengembangan media audio visual berbasis budaya lokal sipakatau, dan bagaimana tingkat kevalidan, kepraktisan, dan keefektifan media audio visual berbasis budaya lokal sipakatau. Hal ini dilakukan dengan tujuan mendapatkan gambaran kebutuhaan pengembangan media audio visual berbasis budaya lokal sipakatau dalam pembelajaran IPS, juga untuk mengetahui rangkaian desain pegembangan medianya, lalu melakukan pengujian untuk mengetahui tingkat kevalidan, kepraktisan, dan keefektifan media tersebut.

Banyak jenis media pembelajaran yang bisa dijadikan sebagai perantara dalam menyampaikan informasi kepada peserta didik. Namun dalam pemilihannya harus tetap memperhatikan beberapa hal terutama karakteristik peserta didik, kebutuhan peserta didik, karakteristik media, lingkungan, bahan ajar, dan tujuan pembelajaran. Prinsip pemilihan media yang dikemukakan oleh Musfiqon (2012: 116) bahwa ada tiga prinsip utama yang bisa dijadikan bagi guru dalam memilih media pembelajaran, yaitu efektif dan efisien, prinsip relevansi, dan prinsip produktivitas.

Media audio visual yaitu media yang dapat didengar dan dilihat. Sebagaimana yang diungkapkan oleh Arsyad (2017: 91) bahwa media audio visual adalah penggabungan media visual dengan suara latar yang berpedoman pada naskah yang telah dirancang sebelumnya. Naskah dalam media audio visual berperan penting sebagai pengarah alur media. Oleh sebab itu langkah awal untuk membuat media audio visual adalah penulisan naskah yang berpatokan pada tujuan pembelajaran dan jabaran materi. Naskah menjadi pedoman dalam mengumpulkan storyboard (papan cerita) sebagai bahan pembuatan media audio visual. Naskah lalu dikembangkan dalam tulisan narasi, oleh Arsyad diuraikan beberapa petunjuk praktis penulisan narasi yaitu (1) tulisan narasi harus singkat, padat, dan sederhana, seperti menulis judul berita, pendek, tepat, berirama, dan mudah diingat, (2) menghindari istilah teknis, kecuali jika diberi batasan atau gambaran, (3) menulis hal-hal yang penting saja, maksimal 15 kata dalam setiap kalimat, dan setiap kalimat minimal memiliki waktu tayang kurang lebih 10 detik (4) kalimat ditulis dalam bentuk kalimat aktif, (5) setelah tulisan narasi rampung, maka tulisan tersebut dibacakan dengan suara keras, lalu lakukan revisi terhadap naskah yang dianggap kurang penting. Narasi yang telah dibuat, lalu direkam dan dijadikan suara latar terhadap gambar atau video yang ditampilkan. Gambar maupun video merupakan bagian dari storyboard yang disusun sesuai naskah.

Berdasarkan pada lingkungan peserta didik, maka memasukkan nilai-nilai budaya lokal dalam pembelajaran merupakan salah satu kriteria pengembangan media pembelajaran. Siapakatau merupakan salah satu nilai budaya lokal Sulawesi Selatan. Menurut Prawono (2015: 127), Siapakatau berasal dari kata tau yang artinya manusia. Sedangkan sipakatau artinya saling memanusiakan. Oleh karena itu lahirlah konsep kehidupan sosial masyarakat Sulawesi selatan yang menjadikan nilai sipakatau sebagai dasar dalam memanusiawikan manusia agar bisa terjalin sikap saling memahami dan menghargai secara manusiawi. Oleh karena budaya sipakatau ini berasal dari dari kearifan lokal yang diturunkan secara turun temurun dari nenek moyang, maka didalamnya terkandung esensi nilai luhur tentang kemanusiaan dan bersifat universal. Menurut Maida, (2016: 332) Siapakatau merupakan suatu sikap untuk memanusiakan manusia dalam keadaan apapun yang tertuang dalam bentuk sikap saling menghormati dan menghargai sesama manusia tanpa melihat status sosial ekonominya. Budaya sipakatau masih bisa di dapatkan pada masyarakat pedesaan yang masih menjunjung tinggi kebiasaan dan adat istiadatnya.

Pendidikan IPS sangat penting diberikan kepada peserta didik SD, Karena pada jenjang inilah peserta didik mendapatkan bekal 
pengetahuan dasar yang mengkaji hubungan dengan lingkungan masyarakat. Menurut Trianto (2010: 176) Tujuan utama pembelajaran IPS adalah untuk mengembangkan potensi peserta didik agar mereka peka terhadap masalah sosial yang sedang terjadi di masyarakat, memiliki sikap mental yang positif terhadap perbaikan segala ketimpangan yang sedang terjadi baik yang terjadi pada dirinya maupun masyarakatnya.

\section{METODE}

Jenis penelitian ini adalah penelitian dan pengembangan (Research and Development atau $R \& D$ ) yang dilakukan di Gugus SDN 57 Campaga Kecamatan Tompobulu, Kabupaten Bantaeng Tahun Pembelajaran 2017/2018. Populasi dan informan dalam penelitian ini adalah 84 peserta didik kelas IV, 7 orang guru kelas IV, dan 7 orang Kepala Sekolah, 1 orang dari Dinas Pendidikan, 1 orang dosen ahli media pembelajaran, dan 1 orang dosen pendidikan IPS dengan teknik penarikan sampel menggunakan random simple sampling. Data dikumpulkan dengan melalui beberapa teknik yaitu studi pustaka, angket, observasi, wawancara, tes hasil belajar, dan dokumentasi. Teknik analisis data yang digunakan yaitu analisis data kombinasi kualitatif dan kuantitatif. Untuk metode kuantitatif digunakan untuk menjawab tentang kebutuhan pengembangan media audio visual berbasis budaya lokal sipakatau, sedangkan metode kuantitatif digunakan untuk menjelaskan gambaran desain pengembangan. juga untuk mengetahui tingkat kevalidan, kepraktisan, dan keefektifan media tersebut. Metode kuantitatif menggunakan analisis deskriptif dan analisis statistik inferensial.

\section{HASIL DAN PEMBAHASAN}

\section{Gambaran Kebutuhan Pengembangan}

Pengembangan media audio visual berbasis budaya lokal sipakatau menjadi sangat penting untuk dilakukan untuk mengatasi permasalahan yang dialami peserta didik yaitu pemilihan dan penggunaan media pembelajaran masih ada yang bersifat konvensional dan monoton, sehingga peserta didik cenderung pasif dalam pembelajaran, dan kadang kala juga guru menggunakan media jadi yang tidak sesuai dengan indikator dan tujuan pembelajaran. Hal ini diperparah dengan tidak difungsikan secara maksimal sarana dan prasarana yang tersedia di sekolah, seperti proyektor (LCD), laptop sekolah dan listrik. Selain itu, pembelajaraan terfokus pada buku panduan pembelajaran IPS yang materinya masih dominan membahas tentang keadaan di luar wilayah Sulawesi Selatan. Sehingga peserta didik kesulitan memahami pembelajaran yang disajikan.

Media pembelajaran audio visual berbasis budaya lokal sipakatau memudahkan peserta didik dalam memahami pembelajaran IPS, karena selain dapat mendengar, peserta didik juga dapat melihat langsung pembelajaran yang ditampilkan. Selain itu, media pembelajaran ini juga penting dalam upaya pembinaan karakter peserta didik agar bisa saling menghormati dan menghargai sesama manusia serta mampu mendekatkan pembelajaran dengan lingkungan sosialnya. Hal ini sangat sinkron dengan muatan kurikulum 2013. Terlebih lagi budaya lokal sipakatau merupakan identitas lokal masyarakat Sulawesi Selatan yang telah mengakar dalam diri dan laku kebudayaan masyarakat. Sehingga memudahkan dalam penerapannya. Idealnya guru tidak hanya bertugas untuk mengajar, tetapi juga dituntut memiliki kreativitas yang tinggi dalam menjalankan tugasnya terutama dalam pembelajaran. kreativitas yang dimaksudkan yaitu salah satunya kreativitas mengembangkan dan memanfaatkan media pembelajaran. hal ini berfungsi untuk mendorong peserta didik berpartisipasi aktif dalam pembelajaran, berpikir kongkrit, memperluas wawasan dan penglaman peserta didik agar membangun struktur konsep dan gagasan yang bermakna demi memudahkan pencapaian tujuan pembelajaran.

Peserta didik kelas IV SD dengan usia 10-11 tahun berada pada tahapan berpikir kongkrit, artinya anak-anak tersebut sudah memahami konsep benda-benda kongkrit dalam hal menyelesaikan masalah. Sehingga tampilan media audio visual berbasis budaya lokal mengasah pikiran peserta didik untuk berpikir konkrit dalam menganalisis tampilan gambar media. materi yang dipelajari adalah "indahnya keragaman negeriku" sesuai dengan pengembangan media audio visual berbasis budaya lokal sipakatau.

Penelitian dan pengembangan media audio visual berbasis budaya lokal sipakatau khususnya dalam pembelajaran IPS bagi peserta didik kelas IV SD sangat dibutuhkan. Selain bisa menumbuhkan partisipasi aktif peserta didik, juga untuk mendekatkan peserta didik pada kehidupan sosial mereka melalui materi pembelajaran yang disajikan guna menciptakan 
pembelajaran yang menyenangkan agar memudahkan pencapaian tujuan pembelajaran.

\section{Desain Pengembangan}

Media pembelajaran ini dikembangkan dengan berbagai pertimbangan kebutuhan pengembangan dan studi literatur. Media pembelajaran audio visual berbasis budaya lokal sipakatau dalam pembelajaran IPS pada peserta didik kelas IV SD se Gugus SDN 57 Campaga Kabupaten Bantaeng didesain dengan urutan yaitu Perumusan tujuan pembelajaran yang telebih dahulu melakukan pemetaan KI, KD, dan IPK, selanjutnya pengembangan materi pembelajaran, penulisan naskah, penulisan narasi, rekaman suara, pengujian internal desain, dan pembuatan produk. Selanjutnya dilakukan uji coba terbatas, revisi produk dari uji coba terbatas, uji coba lapangan utama, revisi produk dari uji coba lapangan utama, uji coba lapangan operasional, revisi produk akhir, dan diseminasi beserta implementasinya.

Kevalidan, kepraktisan, dan keefektifan media audio visual berbasis budaya lokal sipakatau

\section{Hasil uji kevalidan}

Penelitian pengembangan ini melakukan uji kevalidan produk yang meliputi validitas isi dan validitas desain. Validitas isi menunjukkan bahwa media audio visual berbasis budaya lokal sipakatau dikembangkan dengan mengacu pada kurikulum 2013 versi revisi 2017 yang penjabarannya termuat dalam empat KI yang diturunkan ke dalam KD pembelajaran IPS pada peserta didik kelas IV SD. Materi pembelajaran disusun dan dikembangkan berdasarkan KD dan jabaran IPK disesuaikan dengan lingkungan sosial budaya masyarakat setempat dan kebutuhan peserta didik. Begitu pun dengan penyusunan RPP dan LKS. Penggunaan media pembelajaran ini diharapkan dapat merangsang partisipasi aktif peserta didik agar menciptakan pembelajaran yang kreatif dan menyenangkan.

Uji validitas desain dilakukan oleh dua orang ahli yaitu ahli media pembelajaran dan ahli pendidikan IPS. Hasil validasi media pembelajaran beserta instrumennya dinyatakan dalam kategori sangat valid. Olehnya itu, media pembelajaran beserta instrumennya dapat digunakan dalam pembelajaran IPS pada peserta didik kelas IV SD. Meskipun secara keseluran telah telah memenuhi kriteria kevalidan, namun tetap mendapatkan beberapa saran dari ahli untuk digunakan dengan sedikit revisi demi penyempurnaan media pembelajaran dan instrumen yang telah dirancang.

Tabel Rekapitulasi Hasil Validasi Media

\begin{tabular}{|c|c|c|c|c|c|}
\hline $\begin{array}{l}\mathbf{N} \\
\mathbf{0}\end{array}$ & Aspek penilaian & V1 & $\begin{array}{l}\mathbf{V} \\
\mathbf{2}\end{array}$ & $\mathbf{R}$ & $\begin{array}{c}\text { Keteran } \\
\text { gan }\end{array}$ \\
\hline & Aspek format & 3,7 & 4 & 3,8 & $\begin{array}{c}\text { Sangat } \\
\text { valid }\end{array}$ \\
\hline 1 & $\begin{array}{lr}\text { Kejelasan } & \text { petunjuk } \\
\text { penggunaan media untuk } \\
\text { guru }\end{array}$ & 3 & 4 & 3,5 & $\begin{array}{c}\text { Sangat } \\
\text { valid }\end{array}$ \\
\hline 2 & $\begin{array}{l}\text { Kesesuaian pemilihan huruf } \\
\text { dan warna teks }\end{array}$ & 4 & 4 & 4 & $\begin{array}{l}\text { Sangat } \\
\text { valid }\end{array}$ \\
\hline 3 & $\begin{array}{l}\text { Kemudahan penggunaan } \\
\text { media untuk guru }\end{array}$ & 4 & 4 & 4 & $\begin{array}{l}\text { Sangat } \\
\text { valid }\end{array}$ \\
\hline & Aspek Isi & 3,8 & 4 & 3,9 & $\begin{array}{l}\text { Sangat } \\
\text { valid }\end{array}$ \\
\hline 4 & $\begin{array}{l}\text { Kesesuaian pengaturan } \\
\text { gambar dan animasi pada } \\
\text { tampilan media }\end{array}$ & 4 & 4 & 4 & $\begin{array}{c}\text { Sangat } \\
\text { valid }\end{array}$ \\
\hline 5 & $\begin{array}{l}\text { Kesesuaian musik pengiring } \\
\text { dan narasi pada tampilan } \\
\text { media }\end{array}$ & 4 & 4 & 4 & $\begin{array}{c}\text { Sangat } \\
\text { valid }\end{array}$ \\
\hline 6 & $\begin{array}{l}\text { Kesesuaian penyajian materi } \\
\text { dengan media }\end{array}$ & 4 & 4 & 4 & $\begin{array}{c}\text { Sangat } \\
\text { valid }\end{array}$ \\
\hline 7 & $\begin{array}{l}\text { Kejelasan konsep yang } \\
\text { disampaikan melalui media }\end{array}$ & 3 & 4 & 3,5 & $\begin{array}{l}\text { Sangat } \\
\text { valid }\end{array}$ \\
\hline 8 & $\begin{array}{l}\text { Kesesuaian tujuan } \\
\text { pembelajaran dengan media }\end{array}$ & 3 & 4 & 3,5 & $\begin{array}{l}\text { Sangat } \\
\text { valid }\end{array}$ \\
\hline 9 & $\begin{array}{l}\text { Media pembelajaran yang } \\
\text { ditampilkan mudah } \\
\text { dipahami oleh peserta didik }\end{array}$ & 4 & 4 & 4 & $\begin{array}{c}\text { Sangat } \\
\text { valid }\end{array}$ \\
\hline 10 & $\begin{array}{l}\text { Media pembelajaran } \\
\text { mencerminkan budaya local } \\
\text { sipakatau dalam kehidupan } \\
\text { sehari-hari peserta didik }\end{array}$ & 4 & 4 & 4 & $\begin{array}{c}\text { Sangat } \\
\text { valid }\end{array}$ \\
\hline 11 & 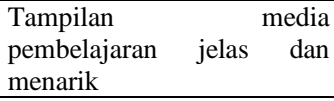 & 4 & 4 & 4 & $\begin{array}{c}\text { Sangat } \\
\text { valid }\end{array}$ \\
\hline 12 & $\begin{array}{lr}\text { Penggunaan } & \text { media } \\
\text { pembelajaran } & \text { membuat } \\
\text { suasana pembelajaran lebih } \\
\text { santai }\end{array}$ & 4 & 4 & 4 & $\begin{array}{c}\text { Sangat } \\
\text { valid }\end{array}$ \\
\hline 13 & $\begin{array}{l}\text { Media pembelajaran sesuai } \\
\text { dengan taraf berpikir dan } \\
\text { kemampuan belajar peserta } \\
\text { didik }\end{array}$ & 4 & 4 & 4 & $\begin{array}{c}\text { Sangat } \\
\text { valid }\end{array}$ \\
\hline 14 & $\begin{array}{lr}\text { Penggunaan } & \text { media } \\
\text { pembelajaran } & \text { membuat } \\
\text { peserta didik terlibat aktif } & \\
\text { dalam proses pembelajaran }\end{array}$ & 4 & 4 & 4 & $\begin{array}{l}\text { Sangat } \\
\text { valid }\end{array}$ \\
\hline & Aspek Bahasa & 4 & 4 & 4 & $\begin{array}{l}\text { Sangat } \\
\text { valid }\end{array}$ \\
\hline 15 & $\begin{array}{l}\text { Kebakuan bahasa yang } \\
\text { digunakan }\end{array}$ & 4 & 4 & 4 & $\begin{array}{l}\text { Sangat } \\
\text { valid }\end{array}$ \\
\hline 16 & $\begin{array}{l}\begin{array}{l}\text { Keefektifan kalimat yang } \\
\text { digunakan }\end{array} \\
\end{array}$ & 4 & 4 & 4 & $\begin{array}{c}\text { Sangat } \\
\text { valid }\end{array}$ \\
\hline 17 & $\begin{array}{l}\text { Kejelasan dan kelengkapan } \\
\text { informasi dalam media yang } \\
\text { disampaikan dengan bahasa } \\
\text { atau kalimat }\end{array}$ & 4 & 4 & 4 & $\begin{array}{c}\text { Sangat } \\
\text { valid }\end{array}$ \\
\hline \multirow[t]{2}{*}{18} & $\begin{array}{l}\text { Kemudahan peserta didik } \\
\text { dalam memahami bahasa } \\
\text { yang digunakan }\end{array}$ & 4 & 4 & 4 & $\begin{array}{c}\text { Sangat } \\
\text { valid }\end{array}$ \\
\hline & Rata-rata total penilaian & 3,8 & 4 & 3,92 & $\begin{array}{c}\text { Sangat } \\
\text { valid }\end{array}$ \\
\hline
\end{tabular}

Penyusunan RPP telah berada pada kategori sangat valid dan tidak mendapatkan revisi. hal ini berdasar pada penyusunan RPP 
dibuat dengan mengacu pada KI, KD, dan IPK yang telah ditentukan sebelumnya. LKS juga sudah berada pada kategori sangat valid namun tetap mendapat sedikit revisi yaitu ruang untuk menuliskan jawaban hasil diskusi kelompok peserta didik masih perlu diperbesar /diperbanyak.

Media audio visual berbasis budaya lokal sipakatau juga sudah berada pada kategori sangat valid. Sekalipun tetap mendapatkan beberapa saran dari ahli yang perlu diperhatikan demi penyempurnaan yaitu Indikator pembelajaran ditampilkan di awal video, identitas video dimunculkan di awal, dan tampilkan ucapan terima kasih pada semua pihak yang telah membantu dalam pembuatan video pada bagian akhir video.

Hasil validasi instrumen juga sudah menunjukkan bahwa seluruh instrumen yang digunakan sudah berada pada kategori sangat valid untuk digunakan sebagai instrumen pengamatan dalam pelaksanaan pembelajaran yang dirancang dengan menerapkan media audio visual berbasis budaya lokal sipakatau yang telah dikembangkan. Meskipun masih ada instrumen yang tetap membutuhkan revisi kecil seperti instrumen tes hasil belajar yang masih perlu direvisi pada bagian petunjuk soal yang perlu mencantumkan alokasi waktu mengerjakan soal dan pada bagian isi yang masih perlu memperbesar ukuran gambar yang dimuat dalam soal. Namun instrumen yang lain seperti angket respon peserta didik, angket respon guru, dan lembar observasi aktivitas peserta didik sudah bisa digunakan tanpa revisi.

Berdasarkan saran dari ahli, setelah melalui tahapan revisi seperti revisi LKS, revisi media dan revisi instrumen tes hasil belajar, maka diperoleh hasil produk dan instrumen penelitian sudah bisa digunakan pada tahapan selanjutnya.

\section{Hasil uji kepraktisan}

Gambaran kepraktisan media audio visual berbasis budaya lokal sipakatau dapat dilihat pada respon guru sebagai pengguna media pembelajaran. Setelah melalui proses pembelajaran dengan menggunakan media audio visual berbasis budaya lokal sipakatau maka guru dapat menyimpulkan hasilnya dalam angket respon guru. Ada beberapa komponen yang bisa dialami langsung oleh guru yakni pemahaman penggunaan media pembelajaran, tepat sasaran dalam pencapaian tujuan pembelajaran, dan penciptaan kondisi pembelajaran yang merangsang peserta didik aktif dan mandiri agar tercupta suasana pembelajaran yang menyenangkan. selain itu, guru juga bisa menilai kesesuaian media pembelajaran dengan tema yang dipilih, kepraktisan penggunaan media pembelajaran, dan kualitas media pembelajaran bisa membuat peserta didik mengerti dan memahami materi dalam pembelajaran. lebih lanjut, guru juga bisa menilai proses pemberian tugas dan evaluasi yang disajikan lebih menarik.

Tabel Rekapitulasi Angket Respon Guru

\begin{tabular}{|c|c|c|c|c|c|c|c|}
\hline \multirow{2}{*}{$\begin{array}{c}\text { No. } \\
\text { aspek } \\
\text { pernya } \\
\text { taan }\end{array}$} & \multicolumn{5}{|c|}{ Responden } & \multirow{2}{*}{$\begin{array}{c}\text { Rer } \\
\text { ata }\end{array}$} & \multirow[t]{2}{*}{ Kategori } \\
\hline & X1 & $\mathrm{X} 2$ & X3 & $\mathrm{X} 4$ & X5 & & \\
\hline 1 & 4 & 4 & 4 & 4 & 4 & 4 & $\begin{array}{l}\text { Sangat } \\
\text { praktis }\end{array}$ \\
\hline 2 & 4 & 3 & 4 & 4 & 4 & 3,8 & $\begin{array}{l}\text { Sangat } \\
\text { praktis }\end{array}$ \\
\hline 3 & 4 & 3 & 4 & 4 & 4 & 3,8 & $\begin{array}{l}\text { Sangat } \\
\text { praktis }\end{array}$ \\
\hline 4 & 4 & 4 & 4 & 4 & 4 & 4 & $\begin{array}{l}\text { Sangat } \\
\text { praktis }\end{array}$ \\
\hline 5 & 4 & 4 & 4 & 4 & 4 & 4 & $\begin{array}{l}\text { Sangat } \\
\text { praktis }\end{array}$ \\
\hline 6 & 3 & 4 & 4 & 4 & 3 & 3,6 & $\begin{array}{l}\text { Sangat } \\
\text { praktis }\end{array}$ \\
\hline 7 & 3 & 3 & 4 & 4 & 4 & 3,6 & $\begin{array}{l}\text { Sangat } \\
\text { praktis }\end{array}$ \\
\hline 8 & 4 & 3 & 4 & 4 & 4 & 3,8 & $\begin{array}{l}\text { Sangat } \\
\text { praktis }\end{array}$ \\
\hline 9 & 4 & 4 & 3 & 4 & 4 & 3,8 & $\begin{array}{l}\text { Sangat } \\
\text { praktis }\end{array}$ \\
\hline 10 & 4 & 4 & 3 & 4 & 3 & 3,6 & $\begin{array}{l}\text { Sangat } \\
\text { praktis }\end{array}$ \\
\hline 11 & 3 & 4 & 4 & 4 & 4 & 3,8 & $\begin{array}{l}\text { Sangat } \\
\text { praktis }\end{array}$ \\
\hline 12 & 4 & 4 & 4 & 4 & 4 & 4 & $\begin{array}{l}\text { Sangat } \\
\text { praktis }\end{array}$ \\
\hline 13 & 4 & 4 & 4 & 4 & 4 & 4 & $\begin{array}{l}\text { Sangat } \\
\text { praktis }\end{array}$ \\
\hline Total & 49 & 48 & 50 & 52 & 50 & & \\
\hline Rata-rata & 3,77 & 3,69 & 3,85 & 4 & 3,85 & & \\
\hline Kategori & $\begin{array}{c}\text { Sangat } \\
\text { praktis }\end{array}$ & $\begin{array}{c}\begin{array}{l}\text { Sangat } \\
\text { praktis }\end{array} \\
\end{array}$ & $\begin{array}{l}\text { Sangat } \\
\text { praktis }\end{array}$ & $\begin{array}{c}\text { Sangat } \\
\text { praktis }\end{array}$ & $\begin{array}{l}\text { Sangat } \\
\text { praktis }\end{array}$ & & \\
\hline
\end{tabular}

Respon guru dijadikan dasar dalam menilai kepraktisan penggunaan media pembelajaran. Hasil dari respon guru terhadap penerapan media audio visual berbasis budaya lokal sipakatau sebagai pengguna media berada pada kategori sangat praktis.

\section{Hasil uji Keefektifan}

Keefektifan penggunaan media audio visual berbasis budaya lokal sipakatau dapat dibuktikan dengan observasi aktivitas peserta didik dalam pembelajaran dan tes hasil belajar peserta didik. observasi aktivitas peserta didik dilakukan pada dua tahapan pengembangan yaitu pada saat uji coba lapangan utama dan pada saat uji coba lapangan operasional. Aspek- 
aspek yang diamati dari aktivitas peserta didik diantaranya adalah kesiapan peserta didik untuk menerima materi pelajaran, antusiasme peserta didik dalan mengikuti kegiatan diskusi kelompok, aktivitas peserta didik dalam kegiatan diskusi kelompok, dan partisipasi peserta didik dalam kegiatan akhir pembelajaran. Hasil observasi yang ditemukan yaitu kedua tahapan ini berada pada kategori sangat baik. selain itu terjadi peningkatan pesentase aktivitas peserta didik dari tahapan uji coba lapangan utama ke tahapan uji coba lapangan operasional. Oleh sebab itu, media audio visual berbasis budaya lokal sipakatau dapat dikatakan efektif digunakan dalam pembelajaran.

Tabel Rekapitulasi Observasi Aktivitas peserta didik

\begin{tabular}{cccccc}
\hline & & Uji & & Uji & \\
N & Aspek yang & coba & & coba & \\
$\mathrm{o}$ & Diamati & lap. & kategori & lap. & Kateg \\
& & utam & & opera & ori \\
& & a $(\%)$ & & sional & \\
& & & $(\%)$ & \\
\hline
\end{tabular}

\begin{tabular}{llcccc}
\hline 1 & $\begin{array}{l}\text { Kesiapan peserta } \\
\text { didik untuk } \\
\text { menerima materi } \\
\text { pelajaran }\end{array}$ & 86.11 & $\begin{array}{c}\text { sangat } \\
\text { baik }\end{array}$ & 86.81 & $\begin{array}{c}\text { sangat } \\
\text { baik }\end{array}$ \\
\hline & $\begin{array}{l}\text { Antuasisme } \\
\text { peserta didik } \\
\text { dalam mengikuti } \\
\text { kegiatan diskusi } \\
\text { kelompok }\end{array}$ & 88.89 & $\begin{array}{c}\text { sangat } \\
\text { baik }\end{array}$ & 89.58 & $\begin{array}{c}\text { sangat } \\
\text { baik }\end{array}$ \\
\hline 3 & $\begin{array}{l}\text { Aktivitas peserta } \\
\text { didik dalam } \\
\text { kegiatan diskusi } \\
\text { kelompok }\end{array}$ & 85.83 & sangat \\
baik & 87.71 & $\begin{array}{c}\text { sangat } \\
\text { baik }\end{array}$ \\
\hline 4 & $\begin{array}{l}\text { Partisipasi peserta } \\
\text { didik dalam } \\
\text { kegiatan akhir } \\
\text { pembelajaran }\end{array}$ & 94.44 & sangat \\
baik & 96.67 & sangat \\
baik
\end{tabular}

Tes hasil belajar peserta didik juga dijadikan acuan dalam menentukan keefektifan media audio visual berbasis budaya lokal sipakatau. Skor rata-rata tes hasil belajar peserta didik setelah pembelajaran lebih besar daripada skor rata-rata sebelum pembelajaran. Hal ini menunjukkan bahwa peserta didik sudah dapat menjawab dengan baik sejumlah soal yang diberikan dan mampu memenuhi nilai Kriteria Ketuntasan Minimal (KKM).

Tabel rekapitulasi Tes Hasil Belajar Peserta didik Tahapan Uji Coba Lapangan Utama

\begin{tabular}{|c|c|c|c|c|c|c|c|c|}
\hline \multirow{2}{*}{ No } & \multirow{2}{*}{ Kategori } & \multicolumn{2}{|c|}{ Frekuensi } & \multicolumn{2}{|c|}{ persentase $(\%)$} & \multirow{2}{*}{$\begin{array}{c}\text { Nilai } \\
\text { Rata- } \\
\text { rata }\end{array}$} & \multirow[b]{2}{*}{$\begin{array}{c}\text { Nilai } \\
\text { Maks }\end{array}$} & \multirow[b]{2}{*}{$\begin{array}{l}\text { Nila } \\
\text { Min }\end{array}$} \\
\hline & & Tuntas & $\begin{array}{c}\mathrm{T} . \\
\text { tuntas }\end{array}$ & Tuntas & $\begin{array}{c}\mathrm{T} . \\
\text { tuntas }\end{array}$ & & & \\
\hline 1 & Pre test & 12 & 18 & 40 & 60 & 63,33 & 80 & 40 \\
\hline 2 & Post test & 29 & 1 & 96.67 & 3,33 & 84,56 & 96,7 & 66.7 \\
\hline
\end{tabular}

Tabel rekapitulasi Tes Hasil Belajar Peserta didik Tahapan Uji Coba Lapangan Operasional

\begin{tabular}{|c|c|c|c|c|c|c|c|c|}
\hline \multirow{2}{*}{ No } & \multirow[b]{2}{*}{ Kategori } & \multicolumn{2}{|c|}{ Frekuensi } & \multicolumn{2}{|c|}{ persentase $(\%)$} & \multirow{2}{*}{$\begin{array}{c}\text { Nilai } \\
\text { Rata- } \\
\text { rata }\end{array}$} & \multirow{2}{*}{$\begin{array}{r}\text { Nilai } \\
\text { Maks }\end{array}$} & \multirow{2}{*}{$\begin{array}{l}\text { Nila } \\
\text { Min }\end{array}$} \\
\hline & & Tuntas & $\begin{array}{c}\text { T. } \\
\text { tuntas }\end{array}$ & Tuntas & $\begin{array}{c}\text { T. } \\
\text { tuntas }\end{array}$ & & & \\
\hline 1 & Pre test & 7 & 33 & 17.50 & 82.50 & 58.75 & 80 & 40 \\
\hline 2 & Post test & 39 & 1 & 97.5 & 3.33 & 82.92 & 96,7 & 66.7 \\
\hline
\end{tabular}

Penilaian tidak hanya sebatas itu, tetapi juga dilakukan penilaian dengan normalisasi gain. Pada tabel distribusi frekuensi dan persentase gain score, hasil belajar peserta didik menunjukkan besarnya peningkatan nilai hasil belajar peserta didik sebelum dan sesudah penerapan media audio visual berbasis budaya lokal sipakatau. selain itu juga dilakukan uji $t$ Paired SPSS yang menunjukkan nilai $\operatorname{sig} \alpha=$ $0,000<0,05$ bahwa terdapat perbedaan tes hasil belajar sebelum dan sesudah penerapan media audio visual berbasis budaya lokal sipakatau. 


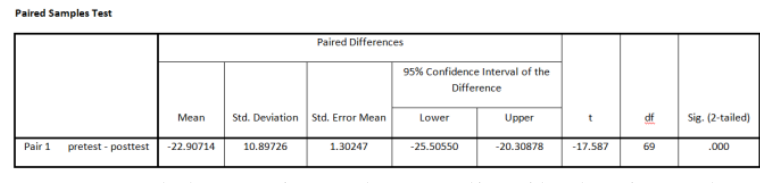

Olehnya itu, dapat ditarik kesimpulan bahwa berdasar pada hasil belajar peserta didik, media audio visual berbasis budaya lokal sipakatau efektif digunakan dalam pembelajaran IPS pada peserta didik kelas IV.

\section{SIMPULAN DAN SARAN}

Hasil analisis kebutuhan diperoleh gambaran bahwa media audio visual berbasis budaya lokal sipakatau dalam pembelajaran IPS sangat dibutuhkan untuk memudahkan peserta didik memahami pembelajaran IPS dengan penyajian pembelajaran yang kreatif dan menyenangkan. Selain itu, juga menjadi salah satu upaya untuk melestarikan nilai-nilai budaya lokal, dan sekaligus menjadi sarana pembinaan karakter peserta didik agar bisa saling menghormati dan menghargai sesama manusia.

Media audio visual berbasis budaya lokal sipakatau dalam pembelajaran IPS didesain dengan urutan yaitu Perumusan tujuan pembelajaran yang telebih dahulu melakukan pemetaan KI, KD, dan IPK, selanjutnya pengembangan materi pembelajaran, penulisan naskah, penulisan narasi, rekaman suara, pengujian internal desain, dan pembuatan produk.

Hasil pengujian validasi oleh ahli menunjukkan bahwa media audio visual berbasis budaya lokal sipakatau dalam pembelajaran IPS sangat valid. uji kepraktisan menunjukkan kriteria sangat praktis berdasarkan respon guru. Tes hasil belajar dan aktivitas peserta didik dalam pembelajaran menunjukkan kriteria efektif. Hal ini berarti media pembelajaran audio visual berbasis budaya lokal sipakatau memenuhi tingkat kevalidan, kepraktisan, dan keefektifan digunakan dalam pembelajaran IPS pada peserta didik kelas IV SD se Gugus SDN 57 Campaga Kabupaten Bantaeng.

Media audio visual berbasis budaya lokal sipakatau dapat memotivasi peserta didik aktif dan memudahkan peserta didik memahami pembelajaran IPS, maka disarankan agar guru bisa lebih kreatif dalam memanfaatkan media pembelajaran sesuai dengan materi yang disajikan agar proes pembelajaran tepat sasaran dan sesuai tujuan pembelajaran yang ingin dicapai.

Media audio visual berbasis budaya lokal sipakatau dapat melestarikan nilai-nilai budaya lokal, dan sekaligus menjadi sarana pembinaan karakter peserta didik agar bisa saling menghormati dan menghargai sesama manusia, maka disarankan agar guru mampu menjadikan budaya lokal sipakatau sebagai sebuah pembiasaan dalam pembelajaran dengan menerapkan media pembelajaran tersebut.

Penelitian dan pengembangan ini telah menghasilkan produk media audio visual berbasis budaya lokal sipakatau yang valid, praktis, dan efektif, maka disaranakan kepada guru agar dapat memanfaatkan media pembelajaran ini dengan cara bijaksana agar dapat menciptakan pembelajaran yang kreatif dan menyenangkan.

\section{DAFTAR RUJUKAN}

Ariyani \& Haryanto. 2010. Pembelajaran Multimedia di Sekolah Pedoman Pembelajaran Inspiratif, Konstruktif, dan Prospektif. Jakarta: Prestasi Pustaka Publisher.

Arsyad, Azhar. 2002. Media pembelajaran. Jakarta : PT Raja Grafindo Persada.

Maida, Nur. 2016. Seminar Nasional Pendidikan Ilmu-ilmu Sosial Membentuk Karakter Bangsa dalam Rangka Daya Saing Global. Makassar: Universitas Negeri Makassar.

Musfiqon. 2012. Pengembangan Media dan Sumber Pembelajaaran. Jakarta: Prestasi Pustakaraya.

Prawono, Suaib. Amin, dkk. 2015. Praktik Pengelolaan Keragaman di Indonesia Kontestasi dan Koeksistensi. Yogyakarta: CRCS.

Somantri, M. N. 2001. Menggagas Pembaharuan Pendidikan IPS. Bandung: PT. Remaja Rosdakarya.

Trianto. 2010. Model Pembelajaran Terpadu. Jakarta: Bumi Aksara.

Permendikbud Nomor 22 Tahun 2016 tentang Standar Proses Pendidikan Dasar dan Menengah. 